\title{
Emanuele Crialese's Nuovomondo and the Triumph of the Mediterranean Heritage
}

\author{
By Simonetta Milli Konewko*
}

\begin{abstract}
Hope, commonly perceived as a positive emotion, is defined as a means to reach desirable objectives and to motivate oneself toward the ways to attain them. It triggers a more positive belief toward the future since it allows individuals to open up, remove their fear, and center on the larger situation. The present work focuses on images that generate hope as well as those that suppress it in order to emphasize Crialese's perception of the New World's culture in opposition to the Mediterranean one. Moved by this emotion, the director focuses on the story of a Sicilian family's migration from Sicily to New York at the beginning of the 20th century. Describing their positive beliefs about their future but also those moments that generate despair and lack of understanding, the director highlights his concerns and a paradoxical perception of the New World in opposition to the values of the southern Italian culture they left behind. Through an examination of the modern American culture that infuses hope and optimism while distorting expectations and dreams, Crialese underlines the values of the Mediterranean heritage that emphasizes the affirmation of values internal to human beings and associated with fraternity and solidarity among individuals. At the same time, he expands the drama of the Sicilian family to the masses of people that in the course of the centuries have devoted their energies, expectations, and dreams in lands faraway from home.
\end{abstract}

Keywords: Theories of Emotions, Hope, Despair, Migration, Mediterranean, Culture, Film Studies.

\section{Introduction}

Nuovomondo (Golden Door), a movie directed by Emanuele Crialese in $2006^{1}$, has been considered a success of Italian cinematography, receiving six awards from seven nominations at the Venice Film Festival in 2006, where it was premiered. In examining the movie, some critics focused on sound and visual composition, while others underlined the lack of typical iconography of the time, such as the Statue of Liberty. Nuovomondo recounts the history of 30 million Italians who left the country during the 1900s, drawn by a portal of opportunities to which generations of immigrants have been pulled and not only in America. Specifically, it focuses on the dramatic decision of a Sicilian family who decides to abandon their privation in the native land to seek a better life in America and their perilous journey to Ellis Island.

\footnotetext{
*James F. Miller Professor of Humanities, Department of Philosophy, Lewis \& Clark College, USA.

${ }^{1}$ The Italian film director continued to investigate the problem of immigration also with his last movie titled, Terraferma. For more information about it see the article by Nicola Rapolds (2013).
} 
Although the title means New World, the movie expresses the point of view of the old world represented by Sicilian peasants who are dreaming of a future they cannot even conceive.

I wish to argue that Crialese uses the emotional traits of hope and despair as a means to propose fantastic or genuine images of the new world, with which he examines the social and historical conditions of the immigrants and resists the popular romanticized image of America in his film narrative. In particular, this analysis focuses on the role of the protagonists and their reactions to hope or despair to denounce their position of weakness and at the same time enhance the value of their Mediterranean culture. In order to examine the images and meanings of hope crafted by Crialese in his representation of immigrants as vulnerable figures, I draw upon theories of hope and despair developed by Stan Van Hooft (2011) and Miriam Greenspan (2004). Following these theorists, while hope is considered the expectation that a desired occurrence will take place and it is triggered when something threatening takes place, despair is generally defined as its opposite, a "feeling of empty, desolate, hopeless, brooding over darkness in our world" (Greenspan, 2004, p.3).

\section{Fantastic Images of America}

The fantastic images that Crialese offers of the New World are irrational and idyllic representations of America expressing the immigrants' subconscious. In certain instances, the director proposes specific manipulated scenes that show not only what the characters imagine but also what they feel. Before examining these images, it is important to notice that toward the end of the $19^{\text {th }}$ century, America became the object of inspiration for many skilled artists whose fantasy was efficiently utilized in selling the dream of America. Numerous idyllic images were produced in various objects, such as posters, postcards, holy pictures, and restaurant menus depicting a heavenly life in America or representing fascinating voyages in extraordinary elegant ships and well-dressed people waiting for and waving to the immigrants on the other side of the ocean ${ }^{1}$. The need to change life was perceived as a great necessity among the poor population in Italy at the beginning of the $20^{\text {th }}$ century, and those images facilitated the process of leaving.

Crialese begins his movie in a remote Sicilian village where both women and men are deeply absorbed by their superstitious and religious practices. $\mathrm{He}$ presents a desolated poor countryside where two young girls are looking to be cured by Fortunata, an old healer woman/medicine woman, because one of the

\footnotetext{
${ }^{1}$ Edmondo De Amicis, who travelled in the 'Galileo' toward Uruguay and Argentina, revealed in an article what was really happening during those trips and illustrated the real conditions of passengers travelling in 3rd class. "Ammassati tra pile di carboni, valigie e animali, assieme a ladri e uomini puzzolenti di sporcizia, vi sono donne malate con figli denutriti. Cosa ne e' dell'amichevole gigante glorificato dalla propaganda, che protegge i poveri emogranti col calore della sua carena d'acciaio?"
} 
two was cursed the day she was promised to a rich American. Subsequently, they offer Fortunata some postcards from America that she rejects and asks his grandson to destroy. Focusing on the peasants' hard conditions of life, an establishing shot shows the arid stony poor land of Madonie, where Salvatore Mancuso, Fortunata's son, and his son Angelo are barefooted climbing a steep mountain holding a rock in their mouths. They are offering a sacrifice to God in order to receive a sign that will help them take an essential decision: staying in Sicily or leaving the country.

The sign appears when Pietro, Salvatore's mute son, arrives and shows him some photo-manipulated postcards that portray America as a land of abundance. The protagonist, astonished by the vision of tiny farmers along with huge hens, gigantic carrots, onions, and trees full of coins, and visibly grateful for such a clear and comprehensible signal, thanks and humbly reveres the Lord. Salvatore is hopeful that the decision to leave is the right one and starts his way back home. Then, he gathers his two sons and his mother Fortunata and sells all of his possessions in order to try his luck in America. Thus, the first image of the New World that Crialese proposes is an idyllic representation that triggers the emotion of hope in the protagonist. By doing that, these attractive representations seem to generate a positive consequence in the protagonist because they power Salvatore's spirit, push him forward, inspire him to overwhelm his obstacles, and keep him focused on achieving meaningful objectives. Moreover, by encouraging Salvatore's imagination and risk-taking, they can lead to potential positive transformations.

To fully understand the feelings that distinguish the protagonist's discovery of the New World's wealth, it is important to keep in mind the conditions of life that characterized the existence of many Italians. Salvatore, an illiterate peasant from a small Sicilian village, as many others, is easily impressed by the heavenly reality portrayed in the postcards. The economic and social conditions that Italians experienced, especially in the southern part of the country, were extremely brutal in the $19^{\text {th }}$ century. Many of them had nothing but poverty, supplying food for their family was a daily challenge, and offering meat was a semiannual event. As Morreale and Carola underline, "A family of modest means ate meat twice a year: chicken or a capon for Christmas. And a roaster kid for Easter" (Morreale \& Carola, 2000, p.51). In these bleak and often life-threatening circumstances, hope offers a concrete possibility of survival for Salvatore and his family because it combines a confident attitude with a firm grip on reality, which determines Salvatore's genuine commitment.

In the previous example, hope appears because the protagonist believes that the choice to leave is beneficial as it would alleviate his own present suffering. In Richard S. Lazarus's words "To hope is to believe that something positive, which does not presently apply to one's life, could still materialize and so we yearn for it" (Lazarus, 1999, p.653). Salvatore's aspiration becomes a cognitive process because it originates from his firm conviction in the future outcomes. Richard S. Lazarus underlines the cognitive aspect of the trait of hope when he writes, "Although desire (or motivation) is an essential 
feature, hope is much more than this because it requires the belief in the possibility of a favorable outcome, which gives hope a cognitive aspect and distinguishes it from the concept of motivation, per se" (ibid., p.653). Through the emotion of hope, Salvatore is able to critically value the progress he and his family will undergo if they follow their constructive vision of the future and act accordingly.

Moreover, the emotion of hope is an intellectual and affirmative progression because it activates the protagonist's desire to know deeper the challenges he has to face and act to overcome them. As more and more information becomes accessible, Salvatore turns out to be better informed and produces a more detailed perception and assessment of the circumstances. Alternatively, he might have chosen to remain uninformed and ignorant, or reject, discharge, or misrepresent important evidence. Using manipulated pictures of the New World, the director triggers Salvatore's emotion of hope to empower him to become an agent of his own future. At the same time, Crialese, following Giuseppe Pitré's examination, underlines his vulnerability, simplicity, self-respect, reverence for social solidarity, and love for his family, which are qualities associated with the practical spirit and popular wisdom of the peasants that Crialese values, in contrast to the reality of the new abstract and bureaucratic world.

The immigrants' hopes, expressed through a constructed or surrealist ${ }^{1}$ approach, erupt in the final scene. Crialese offers the image of a river of milk where the male protagonist, his sons, and Lucy, an English woman encountered during the voyage, after having gone through the severe immigrant inspections in Ellis Island, are peacefully swimming toward their destination holding oversized carrots. In the immigrants' eyes, America is seen as a blissful location that offers abundance and richness to all. In fact, milk, which is the first and most nutritious food, is often considered the food of the gods symbolizing spiritual nourishment and immortality. As demonstrated in Isaiah, honey commonly denotes delights because everything sugary in the natural world parallels what is enjoyable and pleasing in the spiritual world (The Bible, Isaiah, 7:14). The biblical reference is clear in this example, recalling the representation of the promised land as "land of milk and honey" (The Bible, Exodus, 3:8) found in Exodus.

With this scene, Crialese depicts also the optimistic feelings following the immigrants' admission to the New World, and their realization that their desired comfortable and rewarding existence is becoming a reality. Hope for a better life is triggered here, as in the previous example, because it is perceived as a tangible possibility. Stan Van Hooft underlines, in fact, that hope is something that is possible and "has some grounding in reality" (Van Hooft, 2011, p.24) while wish does not require that element. Furthermore, he states that "The wish is for an object while the hope is that something will happen" (ibid.). According to Van Hooft, hope implies the recognition that the desired

\footnotetext{
${ }^{1}$ Luis Bunuel affirms that a film appears to be an involuntary imitation of the dream (Short, 2003). For more information about surrealist techniques in cinematic production see, Surrealism and Cinema, by Michael Richardson (2006).
} 
condition is likely to happen. In our example, however, that possibility turns to confidence because it has been sanctioned by a supernatural intervention that in Salvatore's eyes legitimizes his decision and assures the fulfillment of his plan. America is perceived as a definite and concrete location and becomes his "promised land" by God's will. Nevertheless, by linking Salvatore's hopes and vision of America to his religious beliefs, Crialese reduces its romanticized significance because it may be associated with Salvatore's personal spiritual experience. By doing so, the director induces a reconsideration of Salvatore's vision and suggests that hope for a positive future might be linked to individuals' religious conviction. Indeed, the relationship between hope and faith has been the object of extensive studies by scholars of religion. For instance Pope Benedict XVI, in his Encyclical Letter Spe Salvi (2007), undoubtedly affirms that faith is the constituent of hope. The Bible itself presents several examples that testify to the close relationship between the two words or that use them interchangeably. For instance, the Letters to the Hebrews strictly connect the "fullness of faith" (10:22) to "the confession of our hope without wavering" (The Bible, Letters to the Hebrews, 10:23), thus demonstrating the subjective nature of Salvatore's experience.

\section{Realistic Images of America}

Crialese uses a realist approach in the representation of the Mancuso family's entrance in the new world. By offering detailed shots of the reconstructed rooms where the immigrants are welcomed, the ways both the immigrants and the Americans working in the offices are dressed, and the introduction of the English language spoken and translated for them, Crialese offers empirical evidence in support of the representation of reality. Thus, he creates the illusion that the depiction of the protagonists' entrance in Ellis Island, including the portrayal of the physical and psychological tests which demonstrate their suitability to become citizens of the new world, is a faithful representation of the immigrants' arrival.

America is depicted as an organized and controlled society that precisely selects the newcomers according to an incomprehensible logic for Salvatore. The new society accepts individuals who are able to solve aptitude tests but have no practical sense, and appear detached from their own past and reality, such as Lucy. From this point of view, the Mancuso family appears inadequate to, and incompatible with the imposed requirements for several reasons. First of all, they do not know how to speak English and behave correctly. They did not study. Second, as with the majority of people enduring such a compelling and strenuous voyage, they are dirty, they had never seen the mechanism of a shower, and moreover one of them has a physical impediment.

Crialese creates an emotional effect in depicting the family first being separated because of their gender and physical handicap and then listening to the final decision that highlights the immigrants' weakness and vulnerability. A silent close-up shot shows first the grandmother Fortunata's old hand touching 
her grandson's hand, then the camera moves toward their faces showing the old woman's black dress, red necklace and finally their astonished, and desperate faces. Thus, Crialese offers this detailed reconstruction of the protagonists' gestures and physical appearance to add an emotional and suspenseful quality and to stress significant elements in understanding the film narrative.

After this meticulous presentation of the two characters, the director situates them in a broader environment to underline their inadequacy and difference. He presents an establishing shot showing a room similar to a courthouse. Fortunata and Pietro are sitting in front of a table where elegant administrators are looking at papers and on one side the American flag is officially standing. The scene contains specific objects with metonymical functions $^{1}$ that may call viewers to feel a sense of involvement toward the two characters and separation toward the American officials. These items - the American flag, the table separating the officials from the immigrants, the contrasting ways of dressings of the immigrants and the officials-may be perceived as signifying elements that call attention to the immigrants' vulnerability and hopelessness, and the authority's supremacy and control.

Then Crialese focuses on the representation of the Mancuso's family despair. Salvatore is invited to step forward and hear the verdict from the officer, "Your son is mute and cannot be admitted. Your mother is feebleminded and cannot be admitted. What is your decision?" The family's despair is shown through the close shots of Fortunata and Pietro and through Salvatore's simple and unsophisticated language attempting to convince the officers to admit also his mother and son. The shot presenting Salvatore's unrefined speech and the family in the background dumbfounded by the news, depicts the heartbreak situation. While Crialese portrays Angelo hopefully staring at his father, Fortunata and Pietro are looking down to underline their inadequacy, resignation, and desire not to be seen. Hence, they are showing the cultural trait that distrusts and diminishes vulnerability. The director depicts with them the landscape of despair, as analyzed by Greenspan, which foresees feelings of emptiness, hopelessness, and darkness and is part of, along with grief and fear, the painful emotions that society "tends to regard as signs of psychological fragility, mental disorder or spiritual defect" (Greenspan, 2004, p.2). Crialese complicates this representation showing that despair, if properly accepted and directed, brings appropriate solutions. Greenspan clarifies this possibility stating that negative emotions, "are energies that get our attention, ask for expression, transmit information and impel action" (Greenspan, 2004, p.2). However, Crialese's close-up shot of Pietro holding his grandmother's face close to him and negatively turning his head left and right, conveys the sense that they are dominant figures and anticipates development into their actions. After this gesture, Pietro, miraculously speaking for the first time, declares that the grandmother (now unable to speak) decided to go back but

\footnotetext{
${ }^{1}$ According to James Monaco, "A "metonym" is a figure of speech in which an associated detail or notion is used to invoke an idea or represent an object. Etymologically, the word means "substitute naming" (from the Greek meta, involving transfer, and onoma, name)' (Monaco, 2000, p.167).
} 
wants them to remain in the New World. Although the situation is tragic, the director demonstrates that despair may be a constructive emotion expressing individuals' ability to accept the distress mindfully, suggesting that it is inappropriate to consider it as a negative emotion because the problem is not the emotion itself but the individual's inability to tolerate it.

Crialese utilizes the emotion of despair to highlight the old woman's inability to fit into the new society and her consequent conscious decision to go back to Sicily. Crialese reveals Fortunata's inadequacy to function in the new modernized world also in relation to her ability to question its irrational manner of considering individuals. In the light of her challenging the American rules and suggesting a more profound examination of human existence, the old woman refuses to accept the New World's rules silently. She resists and challenges the value of the intelligence test adopted in Ellis Island by simply asking, "Siete Dio voi per decidere chi sono i cristiani che possono entrare nel nuovo mondo?" The previous question, "Are you God to decide which people are able to enter the new world?" reveals Fortunata's acute critical sense but also a cultural background that valued life according to different standards. With Fortunata's account, Crialese suggests historic authenticity, as underlined by Jerre Mangione and Ben Morreale's work, which reports Fiorello La Guardia's criticism of the methods adopted in Ellis Island to examine the socalled, "mental cases" (Mangione \& Morreale, 1992, p.114). La Guardia, who was working as an interpreter, felt that many cases were unjustly considered incapable typically because of the ignorance on the part of the doctors, who were incompetent to understand the immigrants' customs and values (ibid.).

Fortunata's dramatic decision to return to the old country acquires an even more powerful significance in light of the high percentage of suicides committed by deported individuals. Mangione and Morreale state that 3000 immigrants from different nationalities took their life after being refused entry to the country. The frustration of having arrived in the New World and after months of hoping, being rejected was too difficult to tolerate (Mangione \& Morreale, 1992, p.114). Understandably, individuals felt unable to cope with the sense of defeat that such rejection entailed. In opposition, Fortunata's decision not to stay in the United States demonstrates her ability to decide her future and capability to choose a different standard of life.

By the old woman's expulsion from the New World, America's idealized representation is strongly diminished. Crialese presents the new society as inflexible, uncompromising, and aiming to include individuals within established parameters. The director suggests a revision of the romanticized image of the New World and a reevaluation of the Sicilian and Mediterranean way of life.

\section{Conclusions}

This brief examination proposes fantastic and genuine images of America that Crialese offers in combination with the emotion of hope and despair in 
order to underline different representations of the New World and highlight the significance of the Mediterranean heritage. The association between hope and idyllic images of America may reduce the significance of the New World because they are associated with the immigrants' spiritual experiences. Similarly, the emotion of despair is represented in association with a realistic iconographic reconstruction of the environment, suggesting more historic authenticity, and offering a less idealized depiction of the country.

Specifically, Crialese offers a revaluation of a neglected past by deconstructing some paramount representations of the Italian migrants. Rather than relying on the traditional nostalgic tone employed by a great majority of films that deal with migration in the $20^{\text {th }}$ century, Crialese subverts the official and mainstream version. For instance, Ellis Island, one of the most advanced transfer stations in migration history, is depicted as a heartless place of transformation and separation where the immigrants are either granted entrance to the New World or sent back. In capturing the characters' feelings, expectations, and loss involved in the process of displacement, Nuovomondo strips away both the iconography of the perceived successful and powerful Sicilian immigrant and offers instead a touching cinematic account of the traumatic experience that ordinary Sicilians/immigrants face at their entrance to the New World.

Therefore, the process used by the Italian director to show hope and despair toward the characters in the film narrative, prompts new questions about the construction of America as a romanticized place, and reveals an innovative image of the Sicilian immigrant. The director challenges the qualities of inaction and subordination with which the Southerners have often been depicted and which they might have internalized, and proposes a more dynamic role in valuing their heritage. Furthermore, it suggests that the immigrants' southern, cultural, and social ideals need to be valued, preserved, and considered in their own unique perspective. Thus Crialese, subverting the depiction of America, accentuates the independent power of the South that, as Cassano intelligently underlines, "refuses the passive, belated, and impossible imitation of the North" (xxxvi). At the same time, the director calls attention to the desires, struggles, and unanswered pressures that not only Sicilians but thousands of immigrants all over the world faced and still face in their journey, among others, from Sicily to America, Warsaw to Dublin, and Libya to Italy. Consequently, Crialese enlarges the drama of the Sicilian family to the thousands of immigrants who in every historic instance driven by despair and dragged by hope to recreate their expectations and future lives, dare to ask for more.

\section{References}

Cassano, F., 2012. Southern Thought and Other Essays on the Mediterranean. Translated by N. Bouchard and Valerio Ferme. New York: Fordham. 
Greenspan, M., 2004. Healing through the Dark Emotions. The Wisdom of Fear, Grief, and Despair. London: Shambhala.

Lazarus, R.S., 1999. Hope: An Emotion and a Vital Coping Resource against Despair. Hope and Despair, 66(2), pp.653-678.

Mangione, J., \& Morreale, B., 1992. La Storia: Five Centuries of the Italian American Experience. New York: HarperCollins.

Monaco, J., 2000. How to Read a Film. The World of Movies, Media, and Multimedia. New York: Oxford University Press.

Morreale, B., \& Carola, R., 2000. Italian American. The Immigrant Experience. New York: Metro Books.

Pitré, G., 1889. Usi e costumi, credenze e pregiudizi del popolo siciliano raccolti da Giuseppe Pitré. Palermo: L. P. Lauriel di C. Clausen.

Pitré, G., 1913. La famiglia, la casa, la vita del popolo siciliano raccolti da GiuseppePitré. Palermo: L. P. Lauriel di C. Clausen.

Pope Benedict XVI, 2007. "Spe Salvi" - Encyclical Letter of His Holiness Benedict XVI on Christian Hope. [online] Vatican: The Holy See, 30 Nov. 2007. Available from: http://w2.vatican.va/content/benedictxvi/en/encyclicals/documents/hf_ben-xvi_enc_20071130_spe-salvi.html. [Accessed May 6, 2015].

Rapolds, N., 2013. On a Sicilian Island. Boat People who Can't Be Ignored. NYTimes.com - The New York Times, [online]. July 23, 2013. Available from: http://www.nytimes.com/2013/07/24/movies/emanuele-crialesetackles-migration-in-terraferma.html

Richardson, M., 2006. Surrealism and Cinema. New York: Berg.

Short, R., 2003. The Age of Gold: Surrealist Cinema. Creation Books.

The Bible - Contemporary English Version, 2000. London: HarperCollins.

Van Hooft, S., 2011. Hope. Durham: Acumen Publishing. 
